\title{
Microaerobic Conditions Are Required for Magnetite Formation Within Aquaspirillum magnetotacticum
}

\author{
R. P. Blakemore \\ K. A. Short \\ D. A. Bazylinski
}

Department of Microbiology

University of New Hampshire

Durham, New Hampshire

C. Rosenblatt

R. B. Frankel

Francis Bitter National Magnet Laboratory

Massachusetts Institute of Technology

Cambridge, Massachusetts

Abstract The amount of magnetite $\left(\mathrm{Fe}_{3} \mathrm{O}_{4}\right)$ within magnetosomes of the microaerophilic bacterium Aquaspirillum magnetotacticum varies with oxygen and nitrogen supply. The development of optical methods for directly measuring cell magnetism in culture samples has enabled us to quantitate bacterial $\mathrm{Fe}_{3} \mathrm{O}_{4}$ yields. We measured final cell yields, average cell magnetic moments, and magnetosome yields of growing cells. Cultures were grown with $\mathrm{NO}_{3}{ }^{-}, \mathrm{NH}_{4}{ }^{+}$, or both, in sealed, unshaken vials with initial headspace $\mathrm{Po}_{2}$ values ranging from 0 (trace) to $21 \mathrm{kPa}$. 
More than $50 \%$ of cells had detectable magnetosomes only when grown in the range of $0.5-5.0 \mathrm{kPa} \mathrm{O}$. Optimum cell magnetism (and $\mathrm{Fe}_{3} \mathrm{O}_{4}$ formation) occurred under microaerobic conditions (initial headspace $\mathrm{Po}_{2}$ of $0.5-1 \mathrm{kPa}$ ) regardless of the $\mathrm{N}$ source. At optimal conditions for $\mathrm{Fe}_{3} \mathrm{O}_{4}$ formation, denitrifying cultures produced more of this mineral than those growing with $\mathrm{O}_{2}$ as the sole terminal electron acceptor. This suggests that competition for $\mathrm{O}_{2}$ exists between processes involving respiratory electron disposal and $\mathrm{Fe}_{3} \mathrm{O}_{4}$ formation. Oxygen may also be required for $\mathrm{Fe}_{3} \mathrm{O}_{4}$ formation by other species of magnetotactic bacteria.

Bacterial $\mathrm{Fe}_{3} \mathrm{O}_{4}$ appears to persist in sediments after death and lysis of cells. The presence of bacterial $\mathrm{Fe}_{3} \mathrm{O}_{4}$ in the fossil and paleomagnetic records may be of use as a retrospective indicator of sedimentation that has occurred in microaerobic waters.

\section{Introduction}

Magnetotactic bacteria contain intracellular, enveloped, magnetic particles or "magnetosomes" (Fig. 1). The magnetosomes of strains that have been studied consist of $\mathrm{Fe}_{3} \mathrm{O}_{4}$, the iron oxide magnetite (Frankel et al., 1983; Towe and Moench, 1981).

Aquaspirillum magnetotacticum strain MS-1, the most thor-

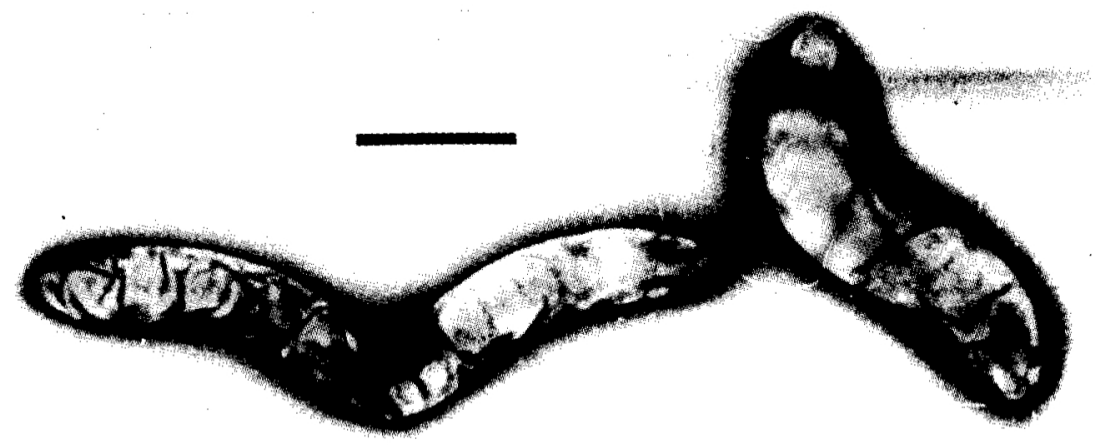

Fig. 1. Transmission electron micrograph of negatively stained cells of $A$. magnetotacticum. Cells contain chains of magnetosomes which are often bisected by division planes. Bar $=1 \mu \mathrm{m}$. 
oughly studied magnetic bacterium, is an obligate microaerophile. Cells denitrify microaerobically and concomitantly consume $\mathrm{O}_{2}$. However, unlike most other denitrifiers, they do not grow under strictly anaerobic conditions, even with $\mathrm{NO}_{3}{ }^{-}$ present (Blakemore et al., 1979; Bazylinski and Blakemore, $1983 a$ ). Rates of growth and intracellular $\mathrm{Fe}_{3} \mathrm{O}_{4}$ formation (Blakemore et al., 1979), denitrification (Bazylinski and Blakemore, 1983a), and nitrogen fixation (Bazylinski and Blakemore, $1983 b$ ) by this organism are noticeably depressed when the initial $\mathrm{O}_{2}$ tension in the culture headspace is greater than $6 \mathrm{kPa}$. Cultures growing with $\mathrm{O}_{2}$ as the terminal electron acceptor (e.g., with $\mathrm{NH}_{4}{ }^{+}$in lieu of $\mathrm{NO}_{3}{ }^{-}$as the sole $\mathrm{N}$ source) contain fewer magnetic cells than those which are denitrifying. However, the effect of $\mathrm{O}_{2}$ and $\mathrm{N}$ source on $\mathrm{Fe}_{3} \mathrm{O}_{4}$ formation by cells has not previously been quantitated due to lack of a suitable method to measure cell magnetism.

We have previously estimated cell magnetism in liquid cultures by microscopically noting the extent to which suspended cells align with an applied magnetic field, or by qualitative estimates of their differential light scattering when cultures are held in a continuously rotating magnetic field (e.g., over a laboratory magnetic stirrer). The cells exhibit optical birefringence, however, and methods have been developed to quantitate cell magnetic moments (values of $\mu$ ) from measurements of magnetic field-dependent birefringence (Rosenblatt et al., 1982).

We undertook the present study to clarify the relationship between available $\mathrm{O}_{2}$ and cell magnetism in cultures grown with $\mathrm{NO}_{3}{ }^{-}$and/or $\mathrm{NH}_{4}{ }^{+}$as the sole $\mathrm{N}$ source. Our findings are relevant to the biogeochemistry of iron, and, if representative of other species, indicate that bacteria produce $\mathrm{Fe}_{3} \mathrm{O}_{4}$ oniy with $\mathrm{O}_{2}$ available but under microaerobic conditions.

\section{Materials and Methods}

A. magnetotacticum was cultured in a chemically defined medium (Blakemore et al., 1979) containing tartaric acid in lieu of succinic as a carbon source, and either $2 \mathrm{mM} \mathrm{NaNO}$, 
$\left(\mathrm{NH}_{4}\right)_{2} \mathrm{SO}_{4}$, or both $\mathrm{N}$ sources, each at $1 \mathrm{mM}$. Cells were inoculated into $155-\mathrm{ml}$ sealed serum vials, each containing $55 \mathrm{ml}$ of culture medium under a gas atmosphere of known composition. Cultures were prepared in triplicate using seven different initial headspace gas compositions: 0.0 (trace) $0.5,1.0,2.5,5.0,10$, and $21 \%(\mathrm{vol} / \mathrm{vol})$ of $\mathrm{O}_{2}$ in $\mathrm{N}_{2}$. It is important to note that the culture system used lacked extensive redox buffering. Medium containing resazurin was colorless prior to inoculation but was faintly pink just afterward. Thus, trace amounts of $\mathrm{O}_{2}$ added with the inoculum were sufficient to allow some cell growth. No sample in this study was strictly anaerobic prior to incubation. In confirmation of earlier published findings, A. magnetotacticum, when tested under stringent conditions of anoxia, failed to grow even with $\mathrm{NO}_{3}{ }^{-}$present. Cultures were each inoculated to $1.3 \times$ $10^{6}$ cells $/ \mathrm{ml}$ and incubated at $30^{\circ} \mathrm{C}$ without shaking. At the end of growth the following were evaluated:

1. cells/ml (by means of direct microscopic counts)

2. magnetosomes per cell (by means of direct transmission electron microscopic examination; magnetosomes within 100 cells from each culture were counted)

3. average cell magnetic moment (by measuring magnetic field-dependent culture birefringence)

The apparatus used to measure magnetic field-dependent culture birefringence has been described (Rosenblatt et al., 1982). Bacteria in $5 \mathrm{ml}$ of culture fluid were fixed with a drop of $10 \%$ glutaraldehyde. Fixed cells in suspension were placed in a 3-ml cuvette (1-cm path length) situated within a Helmholtz coil pair that was used to vary the magnetic field applied to the sample. This entire assembly was placed within a Mumetal canister to cancel the ambient laboratory magnetic field on the cells. The optic axis of the sample was perpendicular to the applied magnetic field. Increases in the field strength over the range 0.1-25.0 Oe produced a corresponding increase in measured birefringence. Only magnetic cells contributed to the measured effect. The data were analyzed to yield the average value and distribution of $\mu$ for those cells. 


\section{Results}

We did not observe total inhibition of growth by high $\mathrm{O}_{2}$ in this study. Cells exhibited a growth lag at high $\mathrm{O}_{2}$ values but, despite their microaerophilic character, they eventually grew. We attribute this to the use of sealed, static cultures, because cells never grew from small inocula on a culture in free exchange with air. Additional studies using systems with constant $\mathrm{Po}_{2}$ are expected to define the precise $\mathrm{O}_{2}$ tension for optimal cell growth and $\mathrm{Fe}_{3} \mathrm{O}_{4}$ formation.

Nevertheless, the results show that more than $50 \%$ of cells in cultures had magnetosomes only when the initial headspace $\mathrm{Po}_{2}$ was between 0.5 and $5 \mathrm{kPa}$ (Tables 1-3; Figs. 2-4). Outside of this narrow range, $\mathrm{Fe}_{3} \mathrm{O}_{4}$ production diminished markedly regardless of the $\mathrm{N}$ source, even though cells grew. The optimal $\mathrm{Po}_{2}$ for $\mathrm{Fe}_{3} \mathrm{O}_{4}$ formation was $1 \mathrm{kPa}$ with $\mathrm{NO}_{3}{ }^{-}$present (Tables 1 , 3 ), or $0.5 \mathrm{kPa}$ with $\mathrm{NH}_{4}{ }^{+}$alone (Table 2). At the optimal $\mathrm{Po}_{2}$, the largest percentage of cells in the population contained magnetosomes (Tables 1-3) and the average number of magnetosomes per cell was also highest (Figs. 2-4). Figs. 2-5 also illustrate the effect of both low and high $\mathrm{O}_{2}$ in inhibiting $\mathrm{Fe}_{3} \mathrm{O}_{4}$ formation by cells. Values of cell magnetic moment were also optimal at approximately $1 \mathrm{kPa} \mathrm{O}$ (Tables 1-3), illustrating the correlation between cell magnetosome content and intrinsic magnetic moment as determined from birefringence measurements. The average magnetic moments measured were those expected from $\mathrm{Fe}_{3} \mathrm{O}_{4}$ grains in the $400-500 \AA$ range.

A somewhat higher value of $\mu$ was obtained for cells grown with trace amounts of $\mathrm{O}_{2}$ and with $\mathrm{NH}_{4}{ }^{+}$as the sole $\mathrm{N}$ source (Table 2) than for those cells provided with $\mathrm{NO}_{3}{ }^{-}$(Tables 1 and 3 ). Since the cells did not grow well on $\mathrm{NH}_{4}{ }^{+}$with trace $\mathrm{O}_{2}$, the relatively high value of $\mu$ (Table 2 ) was strongly influenced by that of the inoculum, which consisted of magnetic cells. The magnetic moment measured was not representative of $\mathrm{Fe}_{3} \mathrm{O}_{4}$ formation during incubation.

At the optimal $\mathrm{Po}_{2}$ for $\mathrm{Fe}_{3} \mathrm{O}_{4}$ formation, the average $\mu$ values for cells cultured with $\mathrm{NO}_{3}{ }^{-}$(Tables 1 and 3) were roughly com- 


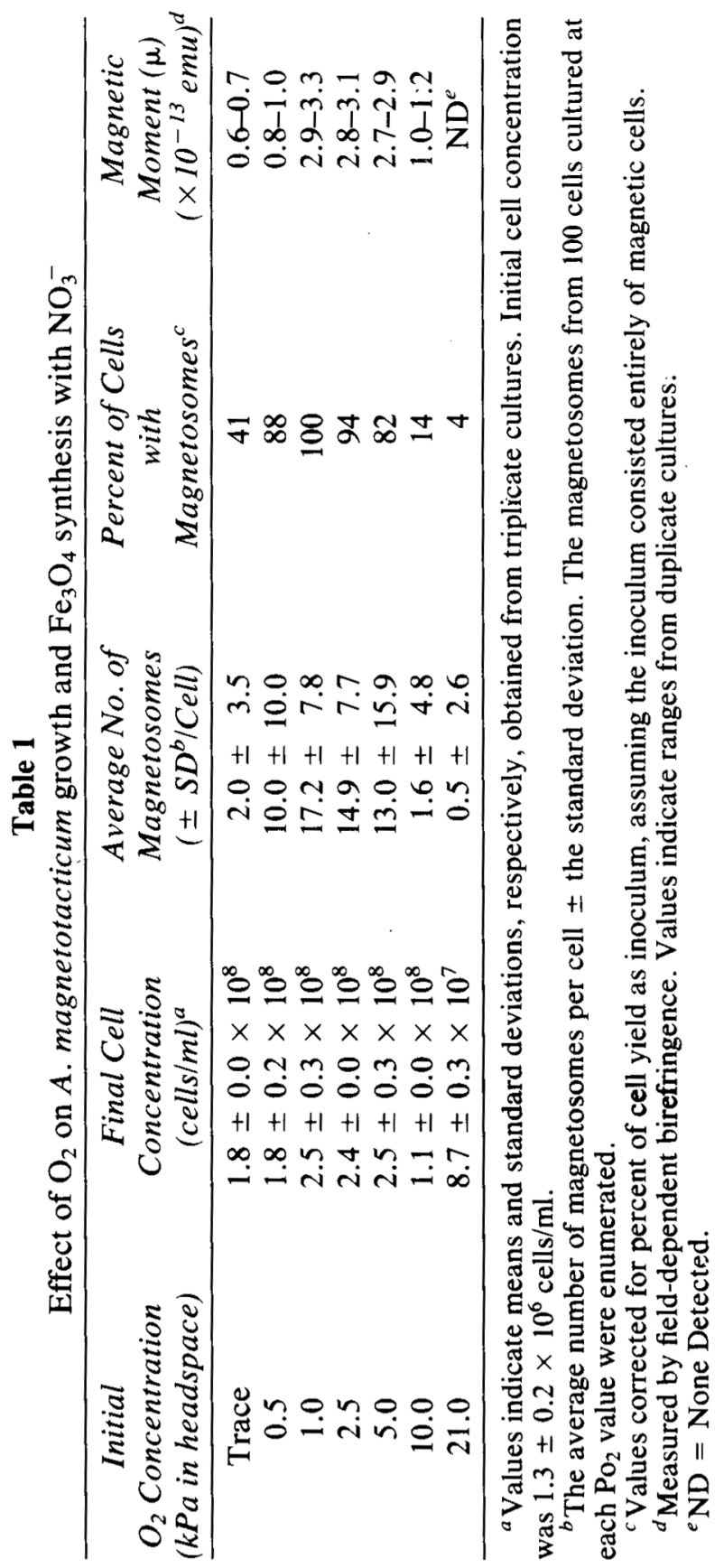




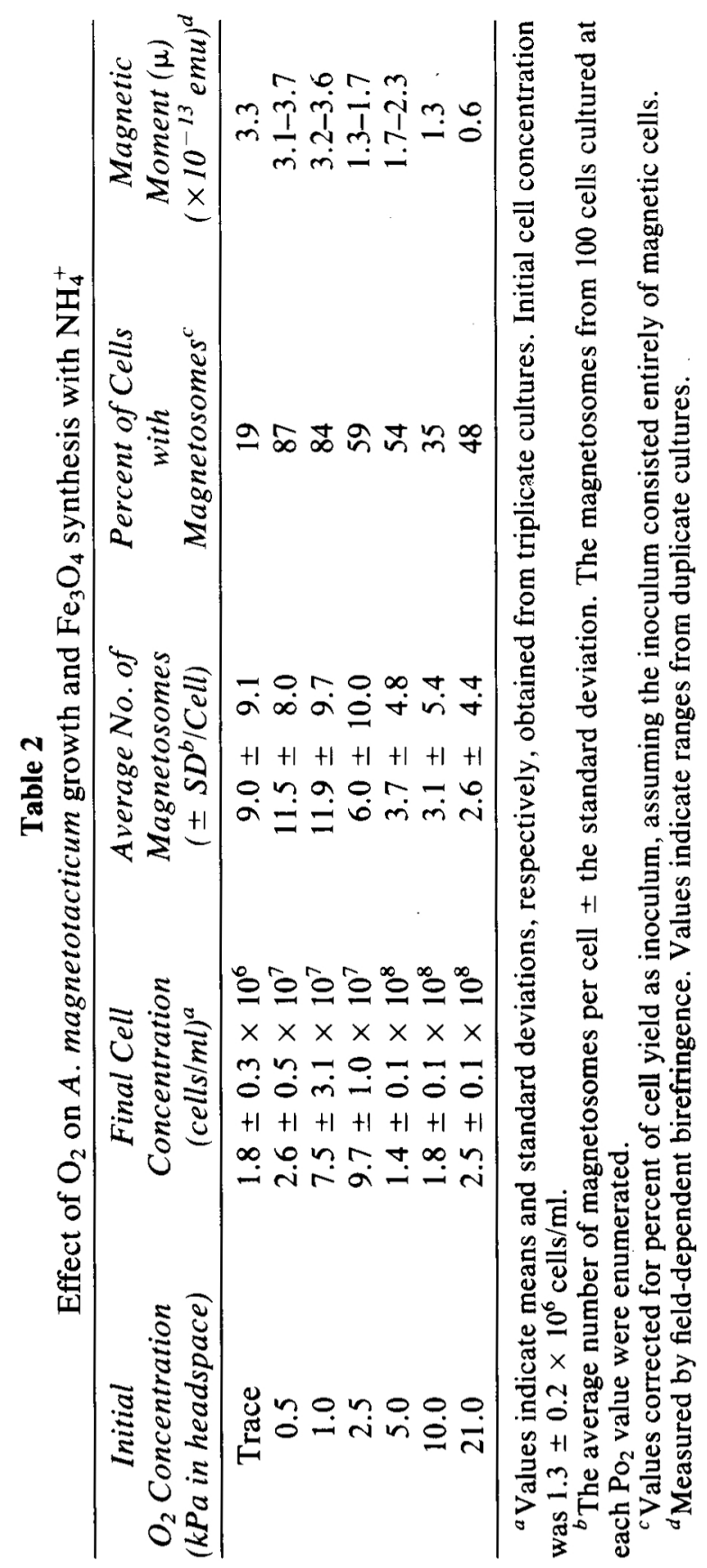



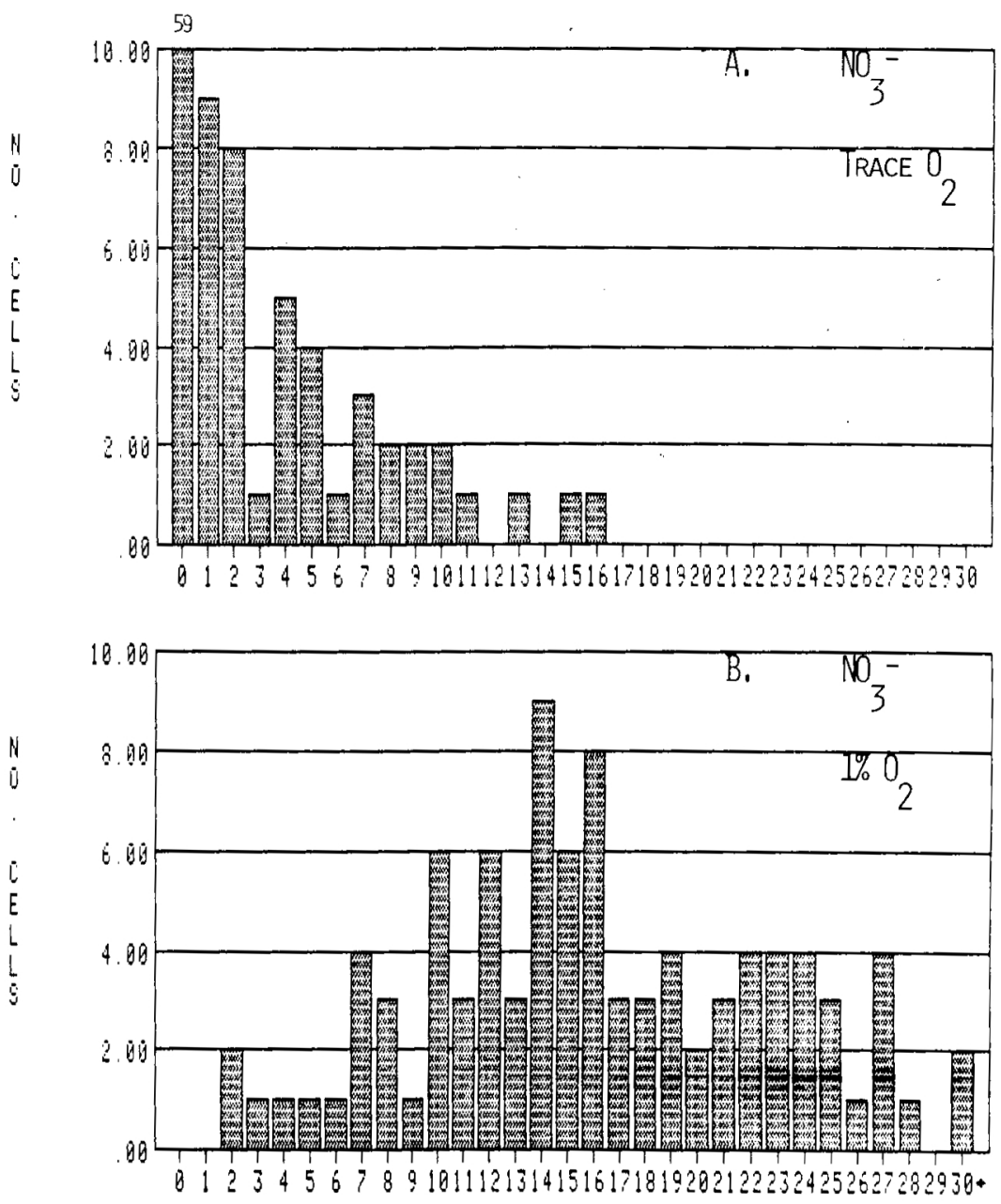

Fig. 2. Magnetosome distributions within $A$. magnetotacticum grown with $\mathrm{NO}_{3}{ }^{-}$and (A) trace, (B) $1 \%$, and (C) $21 \%[\mathrm{kPa}] \mathrm{O}_{2}$. Magnetosomes within 100 cells were counted by means of direct electron microscopy using cultures grown at each $\mathrm{O}_{2}$ tension. Small numbers above the "zero" columns indicate the numbers of cells observed with no magnetosomes. Values of " $30+$ " in abscissas indicate numbers of cells observed that contained 30 or more magnetosomes. 


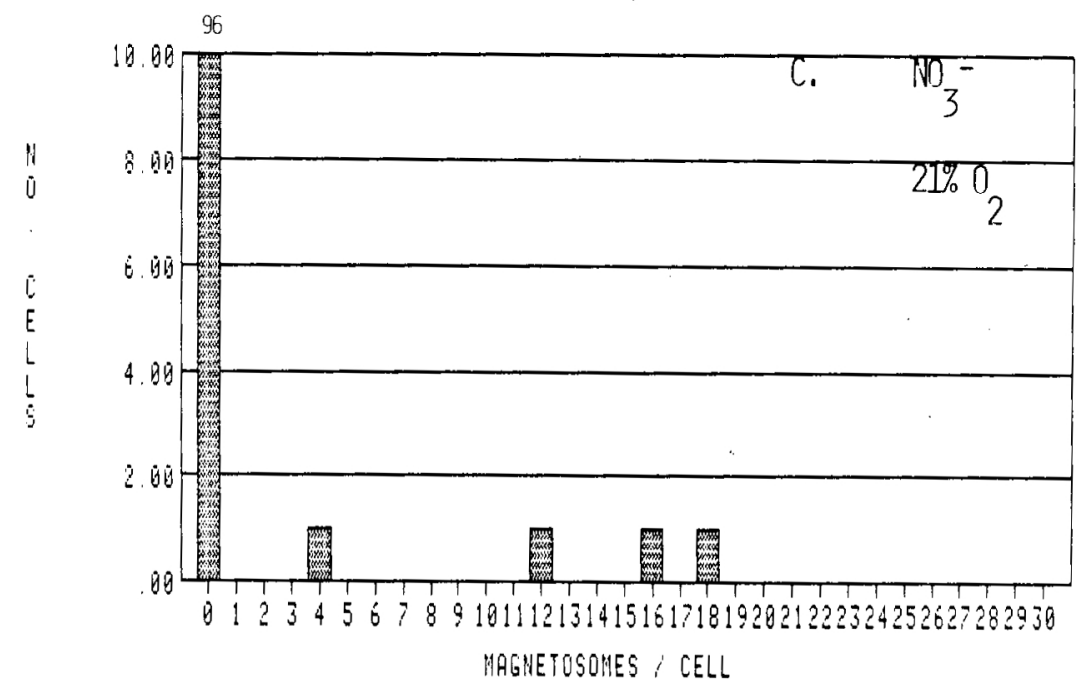

Fig. 2. (Continued)

parable to that of cells grown on $\mathrm{NH}_{4}{ }^{+}$alone (Table 2). However, at the optimal $\mathrm{Po}_{2}, 100 \%$ of cultured cells grown with $\mathrm{NO}_{3}{ }^{-}$alone (Table 1; Fig. 2) possessed magnetosomes, whereas only 84 to $87 \%$ of cultured cells grown with $\mathrm{NH}_{4}{ }^{+}$alone (Table 2; Fig. 3) contained magnetosomes. Furthermore, at their optimum $\mathrm{Po}_{2}$, cells grown with $\mathrm{NH}_{4}{ }^{+}$alone (Table 2) may have produced fewer magnetosomes than cells with $\mathrm{NO}_{3}{ }^{-}$alone (Table 1). The large standard deviations associated with these measurements reflect difficulty in our ability to differentiate between smaller magnetosomes and non-magnetosomes in electron micrographs of whole cells. In addition, during growth in the closed system used, cells may have exhibited variable magnetosome production as $\mathrm{O}_{2}$ and $\mathrm{Fe}$ concentrations changed. The stimulatory effect of $\mathrm{NO}_{3}{ }^{-}$was especially evident, however, when the total $\mathrm{Fe}_{3} \mathrm{O}_{4}$ yield of cultures was evaluated for each value of $\mathrm{O}_{2}$ (Fig. 5). Since $\mathrm{NH}_{4}{ }^{+}$at the concentration used does not repress denitrification (Bazylinski and Blakemore, 1983b), these results verify that $\mathrm{Fe}_{3} \mathrm{O}_{4}$ was produced in greatest quantity by denitrifying cells. This effect appeared to be the result of 

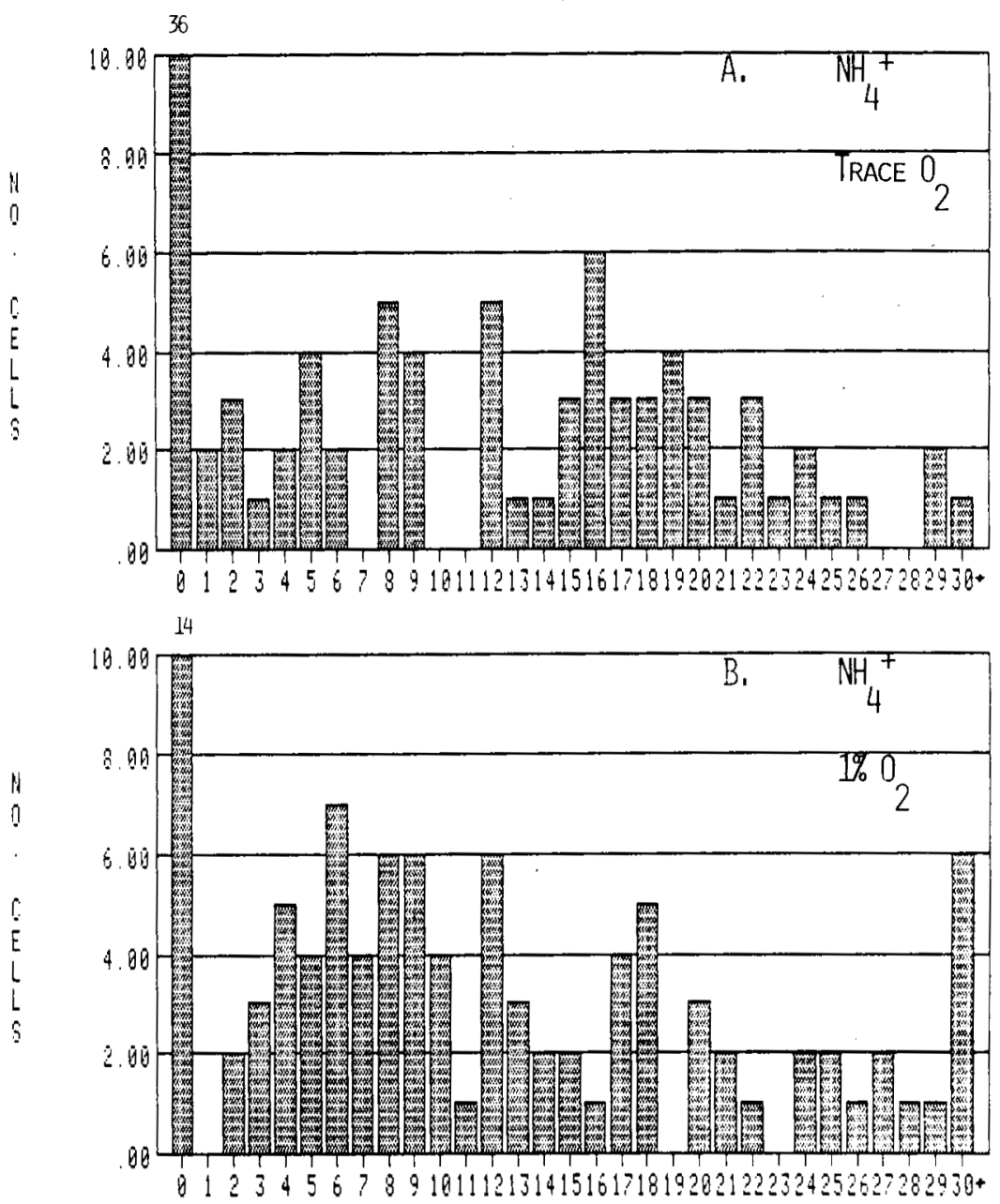

Fig. 3. Magnetosome distributions within A. magnetotacticum grown with $\mathrm{NH}_{4}{ }^{+}$and (A) trace, (B) $1 \%$, and (C) $21 \%[\mathrm{kPa}] \mathrm{O}_{2}$. Magnetosomes within 100 cells were counted by means of direct electron microscopy using cultures grown at each $\mathrm{O}_{2}$ tension (see also legend to Fig. 2).

stimulation by $\mathrm{NO}_{3}{ }^{-}$rather than inhibition by $\mathrm{NH}_{4}{ }^{+}$because at the $\mathrm{Po}_{2}$ optimal for $\mathrm{Fe}_{3} \mathrm{O}_{4}$ formation, the combined effect of the two (Table 3; Fig. 4) was similar to that of $\mathrm{NO}_{3}{ }^{-}$alone (Table 1; Fig. 2). 


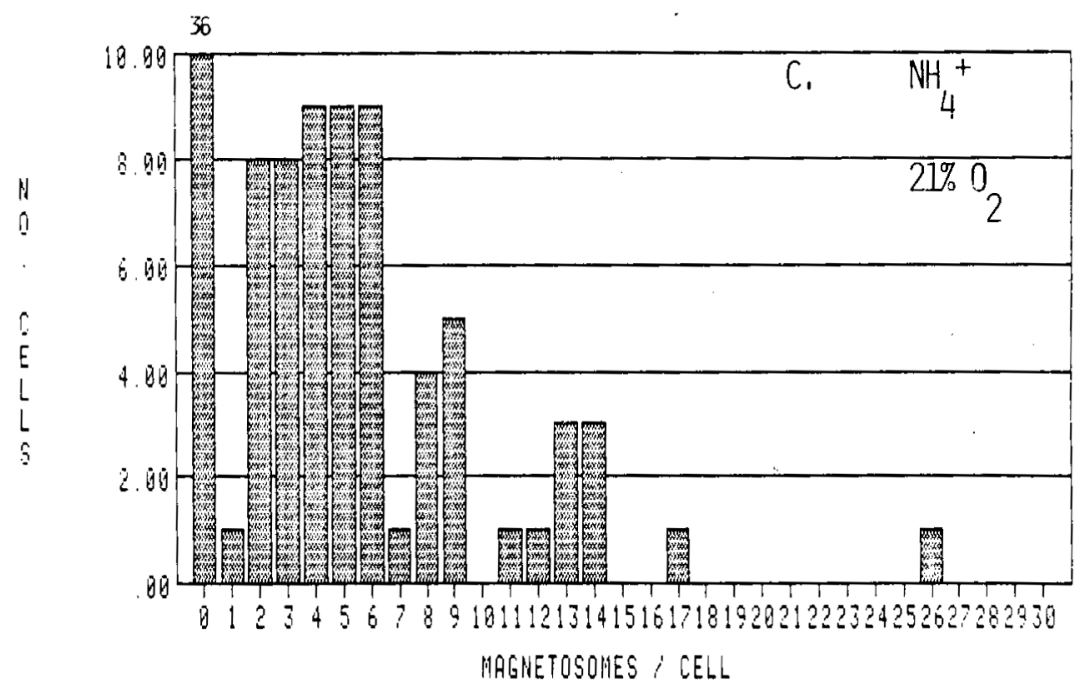

Fig. 3. (Continued)

\section{Discussion}

Lower final growth yields at $<1 \mathrm{kPa} \mathrm{O}_{2}$, regardless of the $\mathrm{N}$ source, illustrate the specific requirement of this organism for $\mathrm{O}_{2}$. The nature of this requirement is unknown but may relate to a need for $\mathrm{O}_{2}$ in biosynthesis. With $\mathrm{NH}_{4}{ }^{+}$as sole $\mathrm{N}$ source, cells at $<1 \mathrm{kPa} \mathrm{O}_{2}$ were also limited by electron acceptor $\left(\mathrm{O}_{2}\right)$. They grew to higher cell yields at low $\mathrm{Po}_{2}$ when supplied with the alternate electron acceptor, $\mathrm{NO}_{3}{ }^{-}$.

The reason for depressed growth of cells with $\mathrm{NO}_{3}{ }^{-}$present at high $(10-21 \mathrm{kPa}) \mathrm{O}_{2}$ is unknown, but may have been due to $\mathrm{O}_{2}$ inhibition of $\mathrm{NO}_{2}{ }^{-}$reduction. The resulting accumulation of $\mathrm{NO}_{2}{ }^{-}$would be toxic for cells (Bazylinski and Blakemore, 1983b).

The data indicate that bacterial $\mathrm{Fe}_{3} \mathrm{O}_{4}$ was produced optimally under microaerobic conditions. More than $50 \%$ of cells had magnetosomes only when the initial headspace $\mathrm{Po}_{2}$ of a sealed culture was between 0.5 and $5 \mathrm{kPa}$. Thus, cells require $\mathrm{O}_{2}$ to produce $\mathrm{Fe}_{3} \mathrm{O}_{4}$. Moreover, since atomic oxygen was always abundant in phosphate and nitrate of the culture medium, only dioxygen satisfied this requirement. 

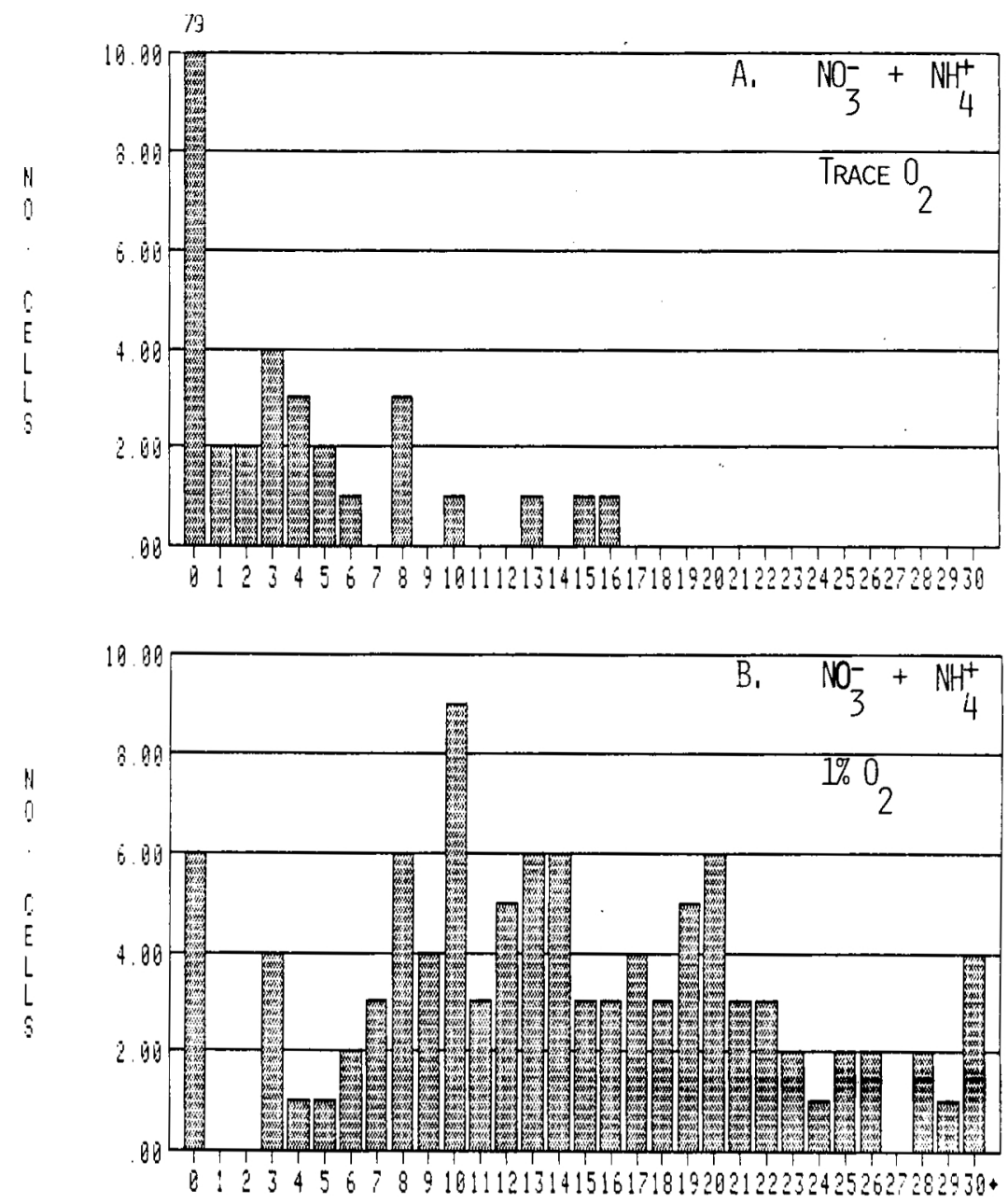

Fig. 4. Magnetosome distributions within $A$. magnetotacticum grown with $\mathrm{NO}_{3}{ }^{-}$plus $\mathrm{NH}_{4}{ }^{+}$and (A) trace, (B) $1 \%$, and (C) $21 \%[\mathrm{kPa}] \mathrm{O}_{2}$. Magnetosomes within 100 cells were counted by means of direct electron microscopy using cultures grown at each $\mathrm{O}_{2}$ tension (see also legend to Fig. 2).

Lower magnetism at low $\mathrm{Po}_{2}$ of cells grown with $\mathrm{NH}_{4}{ }^{+}$, compared to those grown with $\mathrm{NO}_{3}{ }^{-}$, may indicate competition between reactions employing $\mathrm{O}_{2}$ as a terminal electron acceptor and others requiring $\mathrm{O}_{2}$ for formation of the iron oxide, $\mathrm{Fe}_{3} \mathrm{O}_{4}$. Since the bulk of $\mathrm{O}_{2}$ consumed by growing cells is consumed in 


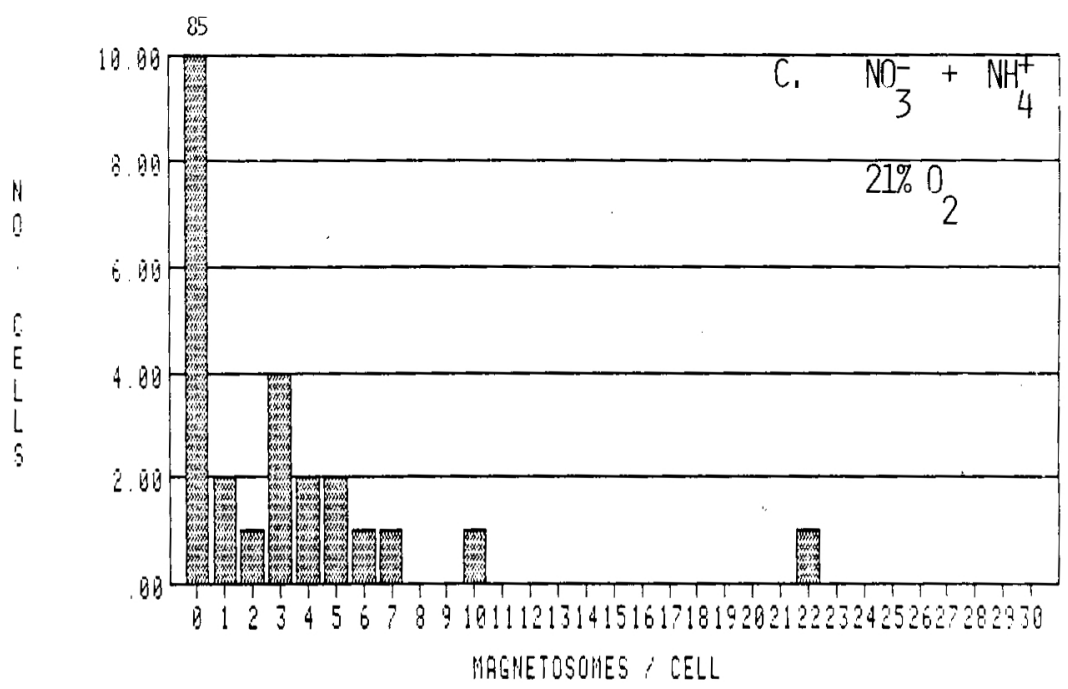

Fig. 4. (Continued)

respiration (unpublished results), the effect of such competition in decreasing the $\mathrm{Fe}_{3} \mathrm{O}_{4}$ yield is most evident with cells grown on $\mathrm{NH}_{4}{ }^{+}$under microaerobic conditions.

The $\mathrm{O}_{2}$ requirement for the formation of $\mathrm{Fe}_{3} \mathrm{O}_{4}$ by bacteria is of considerable physiological interest because cells of this and of at least some other species of magnetotactic bacteria (Spormann and Wolfe, 1984) are aerotactic. As a result of their aerotactic response, cells are directed to, and accumulate in, microaerobic zones optimal for growth and for $\mathrm{Fe}_{3} \mathrm{O}_{4}$ formation.

We believe our findings may have broader implications in biogeochemistry and geology. Magnetotactic bacteria produce $\mathrm{Fe}_{3} \mathrm{O}_{4}$ particles with a narrow size range and with morphologies unique to various species (Matsuda et al., 1983; Mann et al., 1984). Structures with the unique morphology and size of bacterial $\mathrm{Fe}_{3} \mathrm{O}_{4}$ grains have been observed in sediments by several investigators (Blakemore, 1975; W. Ghiorse, personal communication; Kirschvink and Chang, 1984). They apparently persist as magnetic microfossils in sediments after their release from dead bacteria (Fig. 6). Because they are single magnetic domains and have permanent remanent moments, bacterial $\mathrm{Fe}_{3} \mathrm{O}_{4}$ grains might contribute a biological remanent magnetization to sedi- 


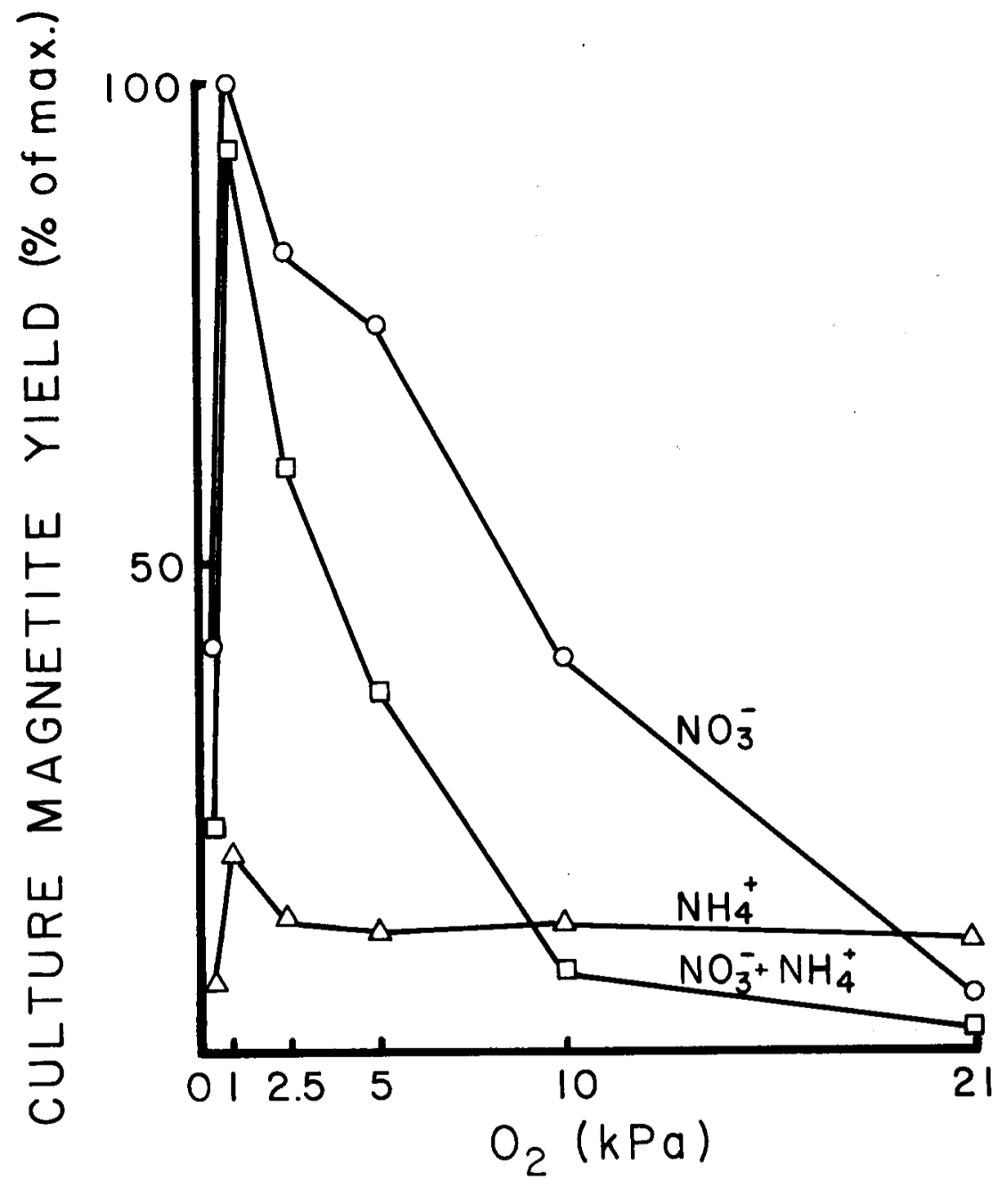

Fig. 5. Total magnetite yield of cultures grown with various sole nitrogen sources at different initial headspace $\mathrm{O}_{2}$ concentrations. Values were obtained by multiplying the average final cell yield by the corresponding average number of magnetosomes per cell. Values are normalized to the maximum yield obtained.

ments containing them. J. L. Kirschvink and S.-B. R. Chang (1984) have determined that the stable, natural remanent magnetization they detected in marine calcareous oozes appeared to 


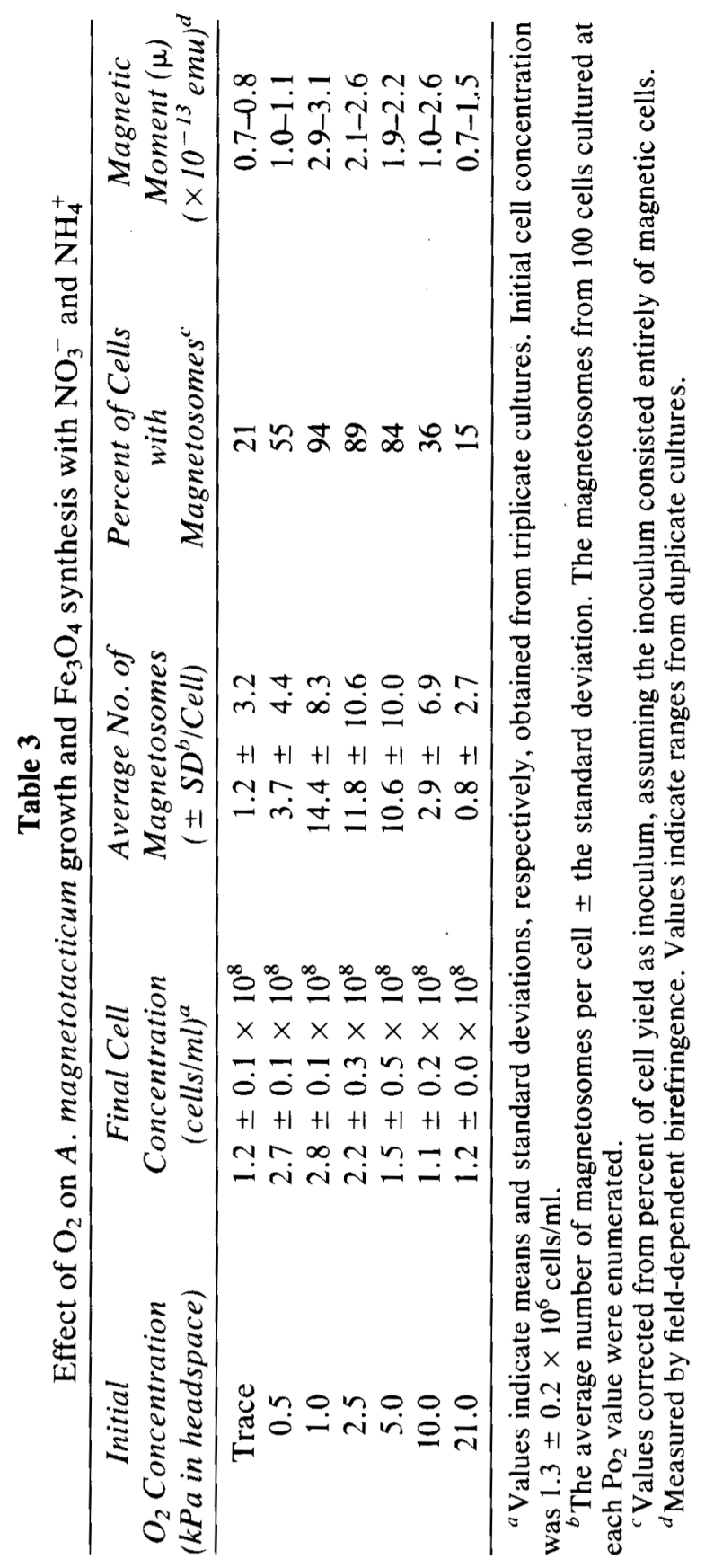




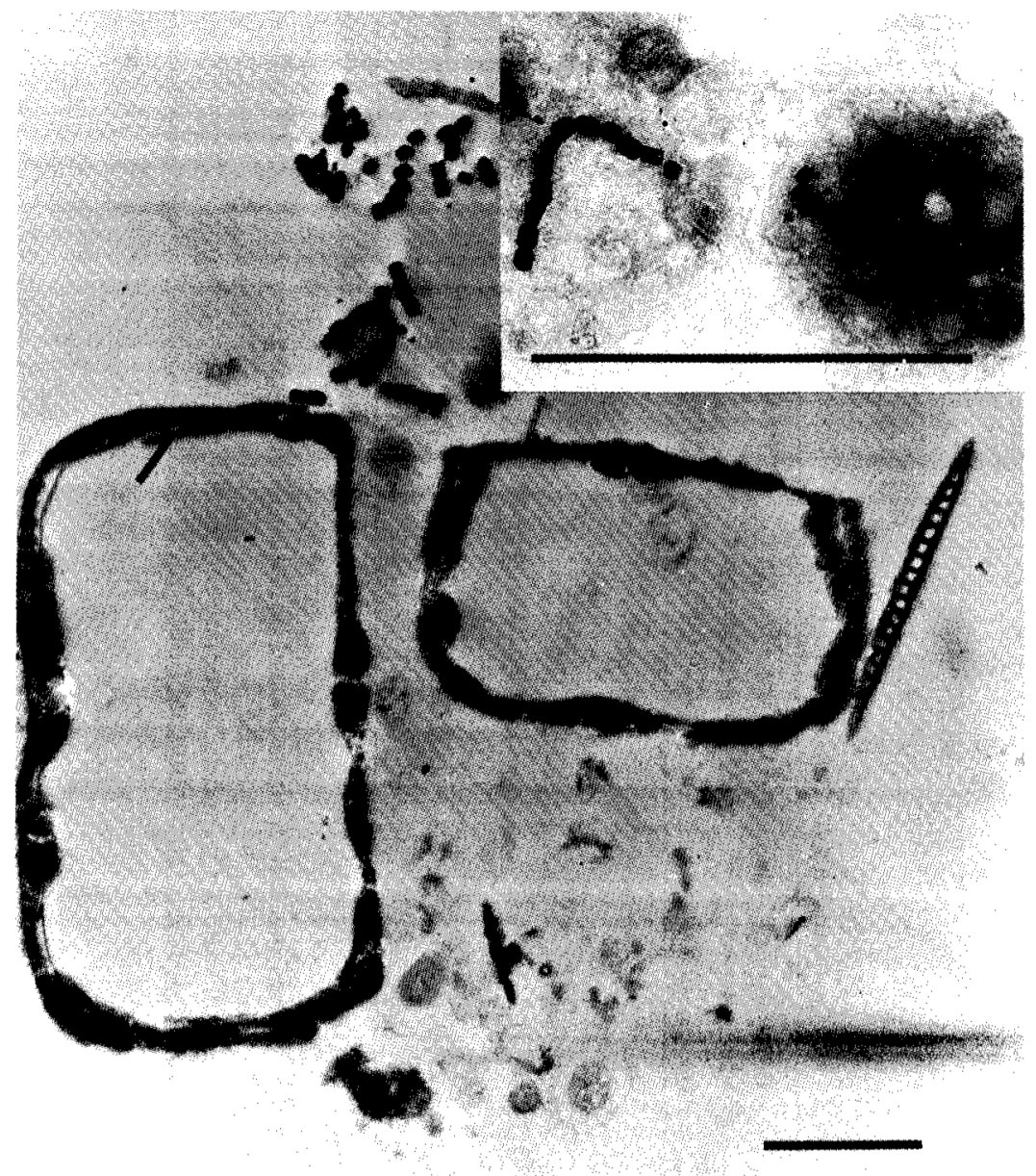

Fig. 6. Transmission electron micrograph of sediment collected from a brackish environment containing magnetotactic bacteria. Thin section stained with uranyl acetate. Note the transverse sections through diatoms as well as through clumps of extracellular particles having a size and morphology of magnetosomes found within bacteria collected at the same site. Inset shows negatively stained magnetotactic bacteria collected from the sediment sample before it was prepared for thin sectioning. Bar $=1 \mu \mathrm{m}$. 
be, in large part, due to single-domain sized $\mathrm{Fe}_{3} \mathrm{O}_{4}$ crystals. The unique size and shape of these grains and their similarity to $\mathrm{Fe}_{3} \mathrm{O}_{4}$ of bacterial origin led these workers to suggest that the magnetotactic bacteria are a prime source of an important component of the paleomagnetic record.

Studies of the occurrence and distribution of other species of magnetotactic bacteria found in natural environments and in enrichments (Blakemore, 1975, 1982; Moench and Konetzka, 1978; Spormann and Wolfe, 1984) lead us to believe that other types of magnetotactic bacteria are also microaerophilic and require $\mathrm{O}_{2}$ for $\mathrm{Fe}_{3} \mathrm{O}_{4}$ formation. For instance, bacterial $\mathrm{Fe}_{3} \mathrm{O}_{4}$ is formed from hydrous ferric oxide precursors produced, in turn, by oxidation of ferrous ions (Frankel et al., 1983). The presence in the fossil record of biogenic structures known to be produced only under microaerobic conditions might provide a useful tool for examining the occurrence of free $\mathrm{O}_{2}$ in the early earth.

Our data, if applicable to other species, demonstrate that bacterial $\mathrm{Fe}_{3} \mathrm{O}_{4}$ formation (hence magnetotaxis) could have evolved only after free $\mathrm{O}_{2}$ became available to cells. This may at first have been in microhabitats shared by oxygenic photoautotrophs, such as in algal mats. Do Precambrian stromatolites or Archean-Early Proterozoic banded iron formations, in particular, preserve evidence of magnetic bacteria? Current thinking suggests that from 1.7 to 2.3 billion years before the present, evolving $\mathrm{O}_{2}$ apparently saturated its principal Archean sinks ( $\mathrm{Fe}^{2+}$ and reduced gases) and began to accumulate in the atmosphere (Walker et al., 1983). During this transition to an oxidizing global atmosphere, the earth's entire atmosphere became, by today's standards, microaerobic. The "microaerophiles," including magnetotactic bacteria, had a thermodynamic edge over cells unable to use $\mathrm{O}_{2}$ as a terminal electron acceptor and may have become the most prevalent physiological group on earth during the Early Proterozoic. As the $\mathrm{O}_{2}$ tension of the atmosphere increased toward its present level, extant species of microaerophiles apparently failed to evolve suitable means of detoxifying damaging products of $\mathrm{O}_{2}$ metabolism. They appear to have once again become restricted in their distribution; this time, however, to microhabitats containing suitably low $\mathrm{Po}_{2}$. 
The acquisition of magnetotaxis and aerotaxis would have helped ensure their localization in these microaerobic zones. It would be interesting if prokaryotic magnetosomes in the fossil and paleomagnetic records provided evidence to test these possibilities and to probe further the details of Earth's early evolution.

\section{Acknowledgments}

We gratefully acknowledge the technical assistance of Nancy Blakemore and Ali Geshnizgani. We are also grateful to S.-B. R. Chang, J. L. Kirschvink, A. M. Spormann, and R. S. Wolfe for sharing unpublished results. This work was supported by a National Science Foundation grant PCM 82-15900. The Francis Bitter National Magnet Laboratory is supported by the National Science Foundation. R.B.F., C.R., K.A.S. and R.P.B. were partially supported by the Office of Naval Research.

\section{References}

Bazylinski, D. A., and R. P. Blakemore. 1983a. Nitrogen fixation (acetylene reduction) in Aquaspirillum magnetotacticum. Curr. Microbiol. 9:305308.

Bazylinski, D. A., and R. P. Blakemore. 1983b. Denitrification and assimilatory nitrate reduction in Aquaspirillum magnetotacticum. Appl. Environ. Microbiol. 46:1118-1124.

Blakemore, R. P. 1975. Magnetotactic bacteria. Science 190:377-379.

Blakemore, R. P. 1982. Magnetotactic bacteria. Ann. Rev. Microbiol. 36:217238.

Blakemore, R. P., D. Maratea, and R. S. Wolfe. 1979. Isolation and pure culture of a freshwater magnetic spirillum in chemically defined medium. J. Bacteriol. 140:720-729.

Frankel, R. B., G. C. Papaefthymiou, R. P. Blakemore, and W. O'Brien. 1983. $\mathrm{Fe}_{3} \mathrm{O}_{4}$ precipitation in magnetotactic bacteria. Biochim. Biophys. Acta. 763:147-159.

Kirschvink, J. L., and S.-B. R. Chang. 1984. Ultra-fine-grained magnetite in deep-sea sediments: Possible bacterial magnetofossils. Geology 12: 559562.

Mann, S., R. B. Frankel, and R. P. Blakemore. 1984. Structure, morphology and crystal growth of bacterial magnetite. Nature 310: 405-407.

Matsuda, T., J. Endo, N. Osakabe, and A. Tonomura. 1983. Morphology and structure of biogenic magnetite particles. Nature 302:411-412.

Moench, T. T., and W. A. Konetzka. 1978. A novel method for the isolation and study of a magnetotactic bacterium. Arch. Microbiol. 119:203-212. 
Rosenblatt, C., F. F. Torres De Araujo, and R. B. Frankel. 1982. Birefringence determination of magnetic moments of magnetotactic bacteria. Biophys. J. 40:83-85.

Spormann, A. M., and R. S. Wolfe. 1984. Chemotactic, magnetotactic, and tactile behavior of a magnetic spirillum. FEMS Lett. 22:171-177.

Towe, K. M., and T. T. Moench. 1981. Electron-optical characterization of bacterial magnetite. Earth Planet. Sci. Lett. 52: 213-220.

Walker, J. C. G., C. Klein, M. Schidlowski, J. W. Schopf, D. J. Stevenson, and M. R. Walter. 1983. Environmental evolution of the Archean-Early Proterozoic earth, p. 260-290. In J. W. Schopf (ed.), Earth's Earliest Biosphere: Its Origin and Evolution. Princeton Univ. Press, Princeton, N.J. 